\title{
KELEKATAN, HARGA DIRI DAN PENYESUAIAN SOSIAL PADA KORBAN PERUNDUNGAN
}

\author{
Erin Ratna Kustanti \\ Fakultas Psikologi, Universitas Diponegoro, \\ Jl. Prof. Soedarto, SH, Kampus Undip Tembalang, Semarang, Indonesia 50275 \\ erintanjung@yahoo.co.id
}

\begin{abstract}
This study aims to investigate the correlation of attachment and self-esteem to social adjustment on victims of bullying. Bullying victims encounter adverse effects that can prolong until adulthood. They also experience poor social adjustment. Good social adjustment associated with self-esteem. A warm and rewarding parenting practices facilitate high self-esteem. Emotional closeness creates strong bonds. Therefore attachment influences the formation of a sense of security for the survival of the child's life in the future. The study population is students who were also bullying victims. The participants were 50 students that were identified using purposive sampling technique. The Social Adjustment Scale, the Attachment Scale, and the Self-Esteem Scale were used to collect data. The results of multiple regression analysis indicated that attachment and self-esteem predict social adjustment on victims of bullying $\left(F(2,47)=5,576 ; p=0,007 ; R^{2}=0,192\right)$. Partially, attachment predicts social adjustment on victims of bullying $\left(F(1,48)=5,201 ; p=0,027 ; R^{2}=0,098\right)$ and self-esteem predicts social adjustment on victims of bullying $\left(F(1,48)=10,713 ; p=0,002 ; R^{2}=0,182\right)$.
\end{abstract}

Keywords: social adjustment; victims of bullying; attachment; self-esteem

\begin{abstract}
Abstrak
Penelitian ini bertujuan untuk mengetahui hubungan antara kelekatan dan harga diri terhadap penyesuaian sosial korban perundungan. Korban perundungan menghadapi dampak buruk yang dapat terus dialami sampai masa dewasa. Korban perundungan mengalami penyesuaian sosial yang buruk. Penyesuaian sosial yang baik berkaitan dengan harga diri. Harga diri yang tinggi terbentuk melalui pola pengasuhan yang penuh kehangatan dan penghargaan. Kedekatan emosional akan memunculkan ikatan yang kuat. Kelekatan memiliki peran dalam pembentukan rasa aman bagi kelangsungan kehidupan anak di masa mendatang. Populasi penelitian ini adalah remaja siswa Sekolah Menengah Pertama yang menjadi korban perundungan. Subyek penelitian berjumlah 50 siswa. Teknik pengambilan sampel menggunakan teknik purposive sampling. Metode pengumpulan data menggunakan Skala Penyesuaian Sosial, Skala Kelekatan, dan Skala Harga Diri. Hasil analisis regresi ganda menunjukkan adanya hubungan antara kelekatan dan harga diri dengan penyesuaian sosial pada korban perundungan $\left(F(2,47)=5,576 ; p=0,007 ; R^{2}=0,192\right)$. Di samping itu secara parsial juga diketahui adanya hubungan antara kelekatan dengan penyesuaian sosial pada korban perundungan $\left(F(1,48)=5,201 ; p=0,027 ; R^{2}\right.$ $=0,098)$ dan hubungan antara harga diri dengan penyesuaian sosial pada korban perundungan $(F(1,48)=$ 10,$\left.713 ; p=0,002 ; R^{2}=0,182\right)$.
\end{abstract}

Kata kunci: penyesuaian sosial; korban perundungan; kelekatan; harga diri

\section{PENDAHULUAN}

Perilaku perundungan masih menjadi pekerjaan rumah bagi berbagai pihak, khususnya pemerintah, sekolah dan orangtua. Sekolah yang bertanggungjawab memberikan rasa aman dan nyaman bagi anak-anak ketika menuntut ilmu serta membantu dalam pembentukan karakter yang berbudi luhur justru menjadi tempat tumbuhnya perilaku perundungan. Praktek kekerasan yang dilakukan secara terus menerus ini bahkan sampai menimbulkan korban. Pemberitaan di media massa menyebutkan terdapat beberapa kasus perundungan yang sampai memakan korban jiwa. 
Data Komisi Perlindungan Anak Indonesia (KPAI) sepanjang tahun 2014 menunjukkan adanya 19 kasus perundungan di sekolah. Jumlah ini berdasarkan pengaduan langsung, melalui media dan melalui surat elektronik. Kasus perundungan ini mulai dari ejekan hingga perlakuan kasar yang menyebabkan luka fisik. Komisi Perlindungan Anak (KPAI) menyampaikan bahwa sejauh ini telah banyak laporan kasus perundungan pada anak dari ejekan, mengadu teman, mengancam bahkan sampai dipaksa minum air toilet. Penelitian yang dilakukan oleh Dr. Amy Huneck dalam Yayasan Semai Jiwa Amini (Sejiwa) Foundation mengungkapkan bahwa 10$60 \%$ siswa di Indonesia melaporkan mendapat ejekan, cemoohan, pengucilan, pemukulan, tendangan, ataupun dorongan, sedikitnya sekali dalam seminggu (Akbar, 2013).

Komponen yang terlibat dalam siklus perundungan adalah pelaku, saksi, dan korban perundungan (Olweus, 1993). Pelaku perundungan biasanya secara fisik memiliki karakteristik lebih besar, kuat, dan lebih tua daripada korbannya, memiliki agresivitas yang tinggi, menyelesaikan permasalahan dengan cara kekerasan, serta memiliki keinginan untuk menguasai dan mendominasi yang tinggi terhadap lingkungannya (Olweus, 1993). Saksi perundungan adalah individu yang menyaksikan peristiwa perundungan. Saksi perundungan dapat memiliki dua peran yang bertolak belakang, yaitu memperpanjang siklus perundungan atau menyelesaikan masalah perundungan. Saksi yang dapat memperpanjang siklus perundungan adalah saksi yang ikut mendukung pelaku perundungan, mengabaikan korban perundungan, dan takut untuk menolong korban. Saksi yang dapat menyelesaikan masalah perundungan adalah saksi yang menyalahkan pelaku perundungan dan menolong korban perundungan ketika mendapatkan ancaman dari pelaku perundungan (Orpinas \& Horne, 2006).

Korban perundungan sebagai individu yang mendapatkan tindakan kekerasan dan gangguan secara berulang-ulang dari pelaku perundungan. Korban perundungan dapat dibedakan menjadi dua kategori berdasarkan respon yang diberikan terhadap pelaku perundungan (Craig, Pepler, Blais, 2007; Fox \& Bolton, 2005; Orpinas \& Horne, 2006; Schwartz, 2000), yaitu : (1) korban submisif, yaitu korban patuh terhadap pelaku, memiliki tingkat kecemasan tinggi, tidak asertif, dan menarik diri; (2) korban provokatif yaitu korban merespon perilaku pelaku perundungan dengan cara impulsif sehingga semakin memancing amarah dari pelaku perundungan untuk terus melakukan perundungan. Korban perundungan submisif dan provokatif mengalami perundungan dalam jangka waktu panjang akibat dari respon yang tidak tepat yang dilakukan korban perundungan pada saat menghadapi peristiwa perundungan, yaitu respon pasif dan provokatif. Respon pasif dan patuh dari korban perundungan akan menjadi penguat positif bagi pelaku perundungan, sedangkan respon provokatif akan semakin memicu amarah dari pelaku perundungan dan memperbesar konflik yang terjadi (Orpinas \& Horne, 2006). Korban submisif adalah korban yang ditetapkan sebagai korban perundungan yang sebenarnya oleh kebanyakan ahli dan paling banyak ditemui di lapangan (Fox \& Bolton, 2005; Orpinas \& Horne, 2006).

Perundungan mendapat perhatian besar di dunia pendidikan dan banyak diteliti karena menimbulkan dampak negatif yang besar terhadap kehidupan di masa anakanak hingga masa dewasa (Pereira, Mendonca, Neto, Valente, Smith, 2004). Perundungan yang diterima secara terusmenerus dan dalam jangka waktu yang panjang, akan memberikan dampak negatif bagi korban (Craig, Pepler, Blais, 2007). 
Perundungan memberikan dampak buruk yang sangat besar. Dampak terburuk adalah hilangnya nyawa korban, baik karena kekerasan fisik yang melampaui ambang batas kekuatan korban atau hilangnya nyawa karena korban depresi, tidak kuat menghadapi tekanan-tekanan dari pelaku perundungan (Rigby, 2007). Selain itu dampak buruk yang dirasakan korban adalah mengalami berbagai macam gangguan yang meliputi kesejahteraan psikologis yang rendah (low psychological well-being) yang ditunjukkan dengan kondisi seperti merasa tidak nyaman, takut, rendah diri, serta tidak berharga, mengeluhkan gangguan fisik, penyesuaian sosial yang buruk di mana korban merasa takut ke sekolah bahkan tidak mau sekolah, menarik diri dari pergaulan, prestasi akademik yang menurun karena mengalami kesulitan untuk berkonsentrasi dalam belajar (Rigby, 2007).

Bauman \& Rio (2006) menjelaskan bahwa pelaku maupun korban perundungan mengalami masalah berkaitan dengan $d r o p$ out dari sekolah, kurangnya penyesuaian sosial, dan perlakuan negatif dari orang lain. Salah satu dampak buruk bagi korban perundungan adalah munculnya masalah penyesuaian sosial yang buruk (Rigby, 2007). Pada dasarnya manusia adalah makhluk sosial yang selalu membutuhkan kehadiran orang lain untuk berinteraksi. Supaya hubungan interaksi berjalan baik manusia diharapkan mampu untuk beradaptasi atau menyesuaikan diri terhadap lingkungan fisik maupun lingkungan sosialnya (Wedjajati, 2008). Schneiders (1999) mengemukakan batasan penyesuaian sosial sebagai usaha individu dengan kemapuan kapasitas yang dimilikinya untuk bereaksi secara efektif dan memadai terhadap realitas sosial adapun tujuan dari usaha tersebut adalah untuk memenuhi tuntutan sosial dengan cara yang dapat diterima dan memuaskan bagi dirinya maupun bagi lingkungannya.
Penyesuaian sosial yang baik ditandai dengan tampilnya respon-respon yang matang, efisien, memuaskan, dan sehat. Respon yang efisien adalah respon yang dapat membawa hasil yang diinginkan tanpa membuang banyak energi, waktu ataupun terjadinya kesalahan. Respon yang sehat adalah respon yang sesuai dengan keadaan diri individu, sesuai dengan hubungan dengan kerabat individu tersebut, dan sesuai dengan hubungan individu dengan Tuhan. Individu yang mampu melakukan penyesuaian sosial yang baik adalah individu yang dengan keterbatasannya, mampu belajar bereaksi terhadap dirinya dan lingkungannya dengan cara yang matang, efisien, sehat dan memuaskan, dan dapat mengatasi konflik-konflik mental, frustrasi, serta kesulitan-kesulitan personal dan sosial tanpa mengembangkan tingkah laku yang simptomatik.

Hurlock (2005) menerangkan bahwa salah satu tugas perkembangan masa remaja yang tersulit adalah yang berhubungan dengan penyesuaian sosial. Remaja harus menyesuaikan diri dengan orang lain diluar lingkungan keluarga. Bagian yang terpenting dan tersulit adalah penyesuaian diri dengan pengaruh kelompok teman sebaya supaya dapat diterima dilingkungan. Pada korban perundungan sulitnya penyesuaian sosial disebabkan karena tidak mampu mengatasi konflik yang dihadapi atau tidak menemukan caracara yang tepat untuk mengatasi masalah atau tuntutan dari lingkungan, sehingga hal tersebut menimbulkan rasa frustrasi. Penyesuaian sosial yang tidak berhasil terjadi karena kondisi tertekan yang dialami individu dan mengakibatkan munculnya tindakan irasional dan tidak efektif, serta mendorong individu melakukan usaha yang tidak realistis untuk menyelesaikan masalah yang dihadapi.

Pelaku maupun korban perundungan memiliki harga diri yang rendah (Bauman \& Rio, 2006). Coopersmith (1998) 
menyatakan bahwa harga diri adalah penilaian yang dibuat seseorang terhadap dirinya. Harga diri seseorang akan terbentuk melalui proses yang sangat panjang sejak seseorang dilahirkan. Klein (dalam Frey \& Carlock, 1987) menyatakan bahwa identitas bayi menyatu dengan orang-orang disekitarnya. Ketika seseorang memasuki masa anak-anak, seseorang akan memperoleh harga diri mereka dari orang tua dan guru. Anakanak belum dapat mengevaluasi diri sendiri karena perkembangan kemampuan kognitif anak belum cukup untuk mengevaluasi diri (Davis-Kean dalam Papalia, Olds, \& Feldman, 2008).

Kualitas harga diri berubah selama masa remaja. Perubahan tersebut umumnya dimulai pada usia sebelas tahun dan mencapai titik yang rendah pada saat usia 12-13 tahun (Rosenberg, dalam Murk, 2006). Pada masa remaja awal kebanyakan remaja mengalami simultaneous challenges yang dapat memberikan pengaruh yang rendah terhadap harga diri remaja. Tantangan-tantangan tersebut meliputi perubahan sekolah, perubahan hubungan antara orangtua dan remaja serta perubahan biologis yang berkaitan dengan pubertas. Harga diri menjadi tidak stabil karena remaja sangat memperhatikan dan mempedulikan kesan yang akan ditampilkan pada orang lain.

Remaja yang memiliki harga diri yang positif memiliki penerimaan diri dan penghormatan diri yang baik. Penerimaan dan penghormatan diri akan menjadikan remaja merasa mampu menyelesaikan tugas, merasa nyaman dengan temanteman, dan bangga dengan diri sendiri. Perasaan bangga ini secara emosional akan mempermudah remaja untuk menjalin interaksi sosial. Sebaliknya, remaja korban perundungan menunjukkan harga diri yang rendah. Remaja korban perundungan cenderung memandang dirinya tidak berharga. Rasa tidak berharga tersebut dapat dilihat dari munculnya rasa tidak berguna dan tidak memiliki kemampuan interaksi sosial. Remaja korban perundungan ini merasa tidak mampu menjalin hubungan dengan temannya. Akibatnya akan mudah dijadikan korban perundungan dan hal ini menjadi permakluman sendiri karena beranggapan bahwa dirinya memang lemah dan pantas untuk di-bully.

Terbentuknya harga diri yang rendah ataupun harga diri yang tinggi tidak terlepas dari peran pengasuhan dalam keluarga. Pola pengasuhan yang ditanamkan orangtua sejak kecil menjadi modal seseorang dalam menghadapi kehidupan dan berinteraksi dengan lingkungan. Pola asuh yang dibentuk oleh orangtua dapat membentuk ikatan emosi antara orangtua dengan anak. Berbagai macam sikap orangtua dalam pengasuhan anak, dilihat dari cara orangtua merespon dan memenuhi kebutuhan anak, akan membentuk suatu ikatan emosional antara anak dengan orangtua sebagai figur pengasuh. Ikatan emosi yang terbentuk antara anak dan orangtua sebagai figur pengasuh oleh Bowlby disebut sebagai kelekatan (Yessy, 2003). Teori kelekatan yang diformulasikan oleh John Bowlby adalah teori yang paling berpengaruh dalam membahas hubungan antara orang tua dengan anak maupun hubungan dekat lainnya. Kelekatan pertama kali terbentuk pada saat anak berusia 6 atau 7 bulan dan kelekatan yang terbentuk adalah terhadap orang tua. Anak yang mempunyai kelekatan dengan orang tua dapat diketahui dari perilaku anak yang selalu ingin dekat dengan orang tua (Sigelman \& Rider, 2003).

Kelekatan akan mengalami perkembangan pada setiap fase kehidupan. Pola kelekatan yang digunakan oleh orangtua akan terinternalisasi pada anak hingga remaja bahkan ketika dewasa. Teori kelekatan dari Bowlby menyatakan bahwa ikatan afeksi yang terjalin antara balita dengan orangtua, yang negatif maupun positif, akan terbawa hingga dewasa (Reeve, 2001). Kelekatan 
adalah konstruk yang berlangsung sepanjang rentang kehidupan, yaitu dari bayi, masa kanak-kanak, dan sampai dewasa, jadi kelekatan tidak hanya terjadi pada masa bayi (Bowlby dalam Doyle \& Moretti, 2000). Berjalannya waktu, pengalaman kelekatan bayi dikonsolidasi ke dalam internal working model terhadap diri sendiri, orang lain dan hubungan dirinya dengan orang lain. Dinamika dari kelekatan bukan hanya hubungan antara orangtua dan anak, namun juga dalam hubungan yang lain sepanjang rentang kehidupan manusia (McAdams, 2003).

Erikson juga menekankan pentingnya hubungan awal antara orang tua dengan anak. Proses mengembangkan trust merupakan hal yang penting pada masa perkembangan anak karena trust adalah dasar untuk mengatasi krisis hidup dalam perkembangan psikososial selanjutnya (Kaplan \& Sadock, 2010). Anak kecil akan mengembangkan perasaan trust kepada orang tua ketika kebutuhan fisik dan emosi anak terpenuhi. Jika tidak terpenuhi, maka anak akan mengembangkan perasaan mistrust, yang akan berpengaruh pada hubungan interpersonal selanjutnya. Hubungan awal antara orang tua dan anak akan membentuk hubungan interpersonal anak pada kehidupan selanjutnya.

John Bowlby \& Inge Bretherton (dalam Doyle \& Moretti, 2000) menjelaskan stabilitas dan pengaruh tetap dari interaksi dengan pengasuh pada masa bayi akan membentuk internal working model yang merupakan representatif dari kognitif mengenai diri mereka sendiri dan orang lain yang nantinya akan digunakan untuk mengintepretasikan suatu kejadian dan membuat harapan mengenai karakter seseorang terhadap hubungan yang ingin dibina dengan orang tersebut. Pengasuh yang sensitif, responsif akan membuat anak mempunyai pikiran bahwa orang lain itu dapat diandalkan, sehingga anak membentuk positive working model. Tapi jika pengasuh anak tersebut tidak sensitif, mengabaikan, dan kasar maka akan membuat anak kurang percaya terhadap orang lain, sehingga anak membentuk negative working model terhadap orang lain. Kelekatan anak akan diperoleh dari internal working model yang terbentuk dari interaksi awalnya dengan pengasuh atau orang tuanya (Shaffer, 2005).

Perubahan yang kompleks banyak terjadi dalam hubungan orang tua dan anak selama masa remaja. Beberapa studi menunjukkan bahwa kelekatan aman terhadap kedua orang tua menurun selama masa remaja Intensitas dan frekuensi dari perilaku kelekatan berkurang sejalan dengan bertambahnya usia, tapi kualitas terhadap ikatan kelekatan relatif stabil (Tverskoy, 2007).

Kemampuan seorang remaja untuk menjaga keseimbangan antara kebutuhan untuk memperoleh kemandirian dengan keinginan untuk tetap berhubungan dengan orang tua merupakan perwujudan dari kelekatan aman (Alan, Moore, \& Kuperminc dalam Doyle \& Moretti, 2000). Jika bayi harus mempunyai secure base untuk bereksplorasi, maka remaja membutuhkan security berupa dukungan dari orang tua agar menjadi individu yang lebih mandiri dan otonomi (Kobak, Kenny \& Rice dalam Sigelman \& Rider, 2003). Remaja yang secure attached dengan orang tua menunjukkan perilaku prososial (Sroufe, 1996), penyesuaian sosial, psikologis yang lebih baik, mampu berpisah dengan orang tua dan membentuk hubungan romantik yang dekat dengan tetap menjaga komunikasi yang baik dengan orang tua (Sigelman \& Rider, 2003).

Penelitian ini bertujuan untuk mengetahui hubungan kelekatan dan harga diri dengan penyesuaian sosial pada korban perundungan. Hasil penelitian ini dapat digunakan sebagai acuan untuk mengembangkan penelitian-penelitian lainnya yang berkaitan dengan 
penyesuaian sosial korban perundungan, serta mengembangkan bentuk-bentuk intervensi yang tepat untuk menyelesaikan kasus perundungan.

\section{METODE}

Penelitian ini menggunakan pendekatan kuantitatif dengan desain korelasi. Variabel yang diukur dalam penelitian ini adalah kelekatan, harga diri dan penyesuaian sosial pada korban perundungan. Populasi dalam penelitian ini adalah remaja korban perundungan. Pemilihan sampel dilakukan dengan teknik purposive sampling. Pengambilan sampel menggunakan teknik purposive sampling, dimana hanya subjek yang terindikasi pernah menjadi korban perundungan yang memenuhi kriteria untuk menjadi subjek penelitian. Penelitian ini diawali dengan proses screening untuk menjaring anggota populasi yang memenuhi kriteria. Screening dilakukan dengan menyebarkan angket deteksi perundungan kepada 315 siswa. Dari hasil screening tersebut diperoleh sebanyak 50 siswa yang menjadi korban perundungan.

Metode pengambilan data dalam penelitian ini menggunakan Skala Penyesuaian Sosial, Skala Kelekatan dan Skala Harga Diri. Skala Penyesuaian Sosial disusun berdasarkan aspek penyesuaian sosial menurut Schneiders (1999) yaitu recognition, participation dan conformity $(\alpha=0,723)$. Skala Kelekatan disusun berdasarkan aspek kelekatan menurut Bowlby (dalam Werner-Wilson \& Davenport, 2003) yaitu attachment behavior, attachment bond, dan attachment behavioral system $(\alpha=0,876)$. Skala Harga Diri disusun berdasarkan aspek harga diri menurut Coopersmith (1998) yaitu kekuatan, keberartian, kebajikan dan kemampuan $(\alpha=0,839)$.

\section{HASIL DAN PEMBAHASAN}

Hasil analisis regresi secara terpisah menunjukkan adanya korelasi positif yang signifikan antara kelekatan dan penyesuaian sosial ( $r=0,313 ; p=0,027)$. Lebih lanjut diketahui bahwa kelekatan memberikan sumbangan efektif kepada penyesuaian sosial sebesar $9,8 \%$ $\left(F(1,48)=5,201 ; p=0,027 ; \mathrm{R}^{2}=0,098\right)$.

Harga diri juga memiliki hubungan yang positif terhadap penyesuaian sosial $(r=0,427 ; \quad p=0,002)$. Artinya semakin tinggi harga diri semakin mudah melakukan penyesuaian sosial. Lebih lanjut diketahui bahwa harga diri memberikan sumbangan efektif kepada penyesuaian diri sebesar 18,2\% $\left(F(1,48)=10,713 ; p=0,002 ; R^{2}=0,182\right)$.

Secara bersama-sama kelekatan dan harga diri juga memiliki hubungan dengan penyesuaian sosial $(r=0,438)$. Lebih lanjut diketahui bahwa nilai $F(2,47)=5,576 ; \mathrm{p}=$ 0,007 dan $R^{2}=0,192$. Artinya secara bersama-sama kelekatan dan harga diri memberikan sumbangan efektif sebesar 19,2\% kepada penyesuaian diri.

Berdasarkan hasil analisis di atas menunjukkan bahwa terdapat hubungan antara penyesuaian sosial dengan kelekatan dan harga diri pada korban perundungan. Hasil analisis juga menunjukkan bahwa variabel penyesuaian sosial dapat dijelaskan oleh variabel kelekatan dan harga diri sebesar 19,2\%. Sedangkan sumbangan lainnya dipengaruhi oleh faktor lain.

Korban perundungan banyak mendapatkan dampak negatif bila terus-menerus mendapatkan perlakuan yang buruk dari teman-temannya (Craig, Pepler \& Blais, 2007). Dampak negatif ini dapat berupa sakit fisik akibat perlakuan kasar dan dampak psikologis yaitu kesejahteraan psikologis (psychological well-being) yang rendah. Hasil penelitian ini menunjukkan 
siswa yang menjadi korban perundungan menunjukkan kesejahteraan psikologis yang rendah, yang ditunjukkan dengan perasaan rendah diri dan penyesuaian sosial yang kurang baik. Hal ini sejalan dengan penjelasan bahwa salah satu dampak buruk bagi korban perundungan adalah munculnya penyesuaian sosial yang buruk (Rigby, 2007).

Penyesuaian sosial yang baik menjadi hal yang penting bagi manusia. Pada remaja, penyesuaian sosial merupakan salah satu tugas perkembangan yang sulit (Hurlock, 2005). Remaja dituntut untuk mulai mampu menyesuaikan diri dengan orang lain diluar lingkungan keluarga. Bagian terpenting dan tersulit adalah penyesuaian sosial terhadap teman sebaya. Hal ini menjadi sangat penting bagi remaja karena pengakuan sebaya menjadi semacam tolak ukur bahwa remaja tersebut berarti, diakui keberadaannya dan diterima dalam kelompok sebayanya.

Penyesuaian sosial yang kurang baik pada korban perundungan akan menjadi faktor yang semakin memperparah kondisi dirinya. Sulitnya penyesuaian sosial akan menjadikan korban perundungan ini semakin mendapat tekanan yang lebih berat lagi dari teman-temannya. Ketidakberdayaan ini berhubungan dengan penilaian terhadap dirinya sendiri atau harga dirinya. Penyesuaian sosial yang kurang baik pada korban perundungan ini berkaitan dengan harga diri yang rendah. Harga diri yang rendah ini ditunjukkan dengan kurangnya kemampuan individu untuk menghadapi konflik akibat dari tekanan yang diberikan oleh temantemannya sehingga reaksi yang muncul adalah ketidakberdayaan dan pembenaran bahwa dirinya memang pantas untuk dirundung (di-bully). Remaja korban perundungan cenderung memandang dirinya tidak berharga. Rasa tidak berharga tersebut dapat dilihat dari munculnya rasa tidak berguna dan tidak memiliki kemampuan interaksi sosial. Remaja korban perundungan ini merasa tidak mampu menjalin hubungan dengan temantemannya.

Terbentuknya harga diri yang rendah tidak dapat dipisahkan dari peran pengasuhan dalam keluarga. Pola pengasuhan yang ditanamkan orangtua sejak kecil menjadi modal seseorang dalam menghadapi kehidupan dan berinteraksi dengan lingkungan. Pola asuh yang dibentuk oleh orangtua dapat membentuk ikatan emosi antara orangtua dengan anak. Berbagai macam sikap orangtua dalam pengasuhan anak, dilihat dari cara orangtua merespon dan memenuhi kebutuhan anak, akan membentuk suatu ikatan emosional antara anak dengan orangtua sebagai figur pengasuh. Teori kelekatan dari Bowlby menyatakan bahwa ikatan afeksi yang terjalin antara balita dengan orangtua, yang negatif maupun positif, akan terbawa hingga dewasa (Reeve, 2001).

Pada masa remaja, kelekatan tetap penting dan diperlukan karena pada masa ini kelekatan dengan orang tua akan mendukung kemampuan remaja untuk menunjukkan penyesuaian sosial yang baik di lingkungannya (Sigelman \& Rider, 2003).

\section{SIMPULAN}

Berdasarkan hasil analisis data, dapat disimpulkan bahwa terdapat hubungan antara kelekatan dan harga diri dengan penyesuaian sosial pada korban perundungan. Kelekatan dan harga diri menyumbang $\quad 19,2 \quad \% \quad$ terhadap penyesuaian sosial.

\section{DAFTAR PUSTAKA}

Akbar, G. (2013). Mental imagery mengenai lingkungan sosial yang baru pada korban bullying. eJournal Psikologi, 1(1), 23-37 
Bauman, S. \& Rio, A. (2006). Preservice teacher responses to bullying scenarios: comparing physical, verbal and relational bullying. American Psychological Association Journal, 98, 219-231.

Coopersmith, S. (1998). The antecedent of self-esteem. San Francisco: W.H Freeman and Company.

Craig, W., Pepler, D., \& Blais, J. (2007). Responding to perundungan, what works? School Psychology International, 28, 465-477.

Doyle, A. B. \& Moretti, M. M. (2000). Attachment to parents and adjustment in adolescence. Literature Review and Policy Implication. Diunduh dari www.phac-aspc.ge.ca

Frey, D. \& Carlock, C. J. (1987). Enhancing self-esteem. Ohio: Accelerated Development.

Fox, C. L. \& Boulton, M. J. (2005). The social skill problems of bullying: self, peer \& teacher perceptions. British Journal of Educational Psychology, 75, 313-328.

Hurlock, E. B. (2005). Psikologi perkembangan suatu pendekatan sepanjang rentang kehidupan. Edisi kesembilan. Alih bahasa: Istiwidayanti, Soedjarwo. Jakarta: Erlangga

Kaplan \& Sadock. (2010). Buku ajar psikiatri klinis. Edisi ke-2. Jakarta: EGC.

McAdams, M.S. (2003). Labelling and delinquency. Adolesence, 38, 171186.

Murk, C.J. (2006). Self-esteem research, theory and practice: Toward a positive psychology of self-esteem.
New York: Spinger Publishing Company.

Olweus, D. (1993). Bullying at school: what we know and what we can do. Oxford: Blackwell.

Orpinas, P. \& Horne, A. M. (2006). Bullying prevention, creating a positive school climate and developing social competence. Washington, DC: American Psychological Association.

Papalia, D. E., Olds, S. W., \& Feldman, R. D. (2008). Human development (Psikologi perkembangan). Jakarta: Kencana Prenada media group.

Pereira, B., Mendonca, D., Neto, C., Valente, L., \& Smith, P. K. (2004). Bullying in Portuguese schools. School Psychology International, 25(2), 241-254.

Reeve, J. M. (2001). Understanding motivation and emotion. Third Edition. Philadelphia: Harcourt College Publishers.

Rigby, K. (2007). Bullying in schools. Melbourne: Australian Council for Educational Research.

Schneiders, A. A. (1999). Personal adjustment and mental health. New York: Holt, Reinhart and Winston Inc.

Schwartz, D. (2000). Subtypes of victims and aggressors in children's peer group. Journal of Abnormal Psychology, 28, 181-192.

Shaffer, D. R. (2005). Social and personality development. USA: Thomson.

Sigelman, C. K. \& Rider, E. A. (2003). Life-span human development, 
Fourth Edition. USA: Thomson Wadsworth.

Sroufe, L. A. (1996). Emotional development: The organization of emotional life in the early years. New York: Cambridge University Press.

Tverskoy, A. (2007). The quality of close adolescent friendships: Roles of attachment, adjustment and problem solving ability. New York: Clinical Psychology Stony Brook University.

Wedjajati, S. R. (2008). Dukungan guru terhadap penyesuaian sosial anak berbakat intelektual. Jurnal Didaktika, 9, 2.

Werner-Wilson, R. J. \& Davenport, B. R. (2003). Distinguishing between conceptualizations of attachment: Clinical implications in marriage and family therapy. Contemporary Family Therapy 25(2), 179-193.

Yessy. (2003). Hubungan pola kelekatan dengan kemampuan menjalin relasi pertemanan remaja. Jurnal Psikologi, 12(2), 1-12. 